\title{
Classical Trends in the Architecture of Botanical Objects in Scandinavia
}

\author{
Zoia Aksenova*, Olga Belousova \\ Saint Petersburg State University of Architecture and Civil Engineering, \\ Vtoraja Krasnoarmejskaja Street, 4, Saint Petersburg, 190005, Russia
}

Received April 15, 2020; Revised June 17, 2020; Accepted July 1, 2020

Copyright@2020 by authors, all rights reserved. Authors agree that this article remains permanently open access under the terms of the Creative Commons Attribution License 4.0 International License

\begin{abstract}
Considering the countries of the Baltic region, it should be noted that historical ties between them stretch from the Viking era and the Swedish Baltic hegemony of the 17th century to our time. The architecture of synthesizing classicism in general and the architecture of historical objects of botanical gardening in the Scandinavian countries remained beyond the attention of Russian architectural historians and experts, which makes the topic of the study relevant. The object of the study is the building of interior botanical gardening with signs of classical influence. The subject of this study is the nature and patterns of the influence of classical trends on the architectural and urban planning characteristics of buildings of interior botanical gardening in the studied cities of Norway and Sweden of the 18-19th centuries. Chronological boundaries: the period under consideration covers the period from the 1840s to the end of the 19th century. Territorial boundaries of the study: the largest cities in Sweden (Stockholm, Uppsala, Lund) and Norway (Oslo). The study of the regional features of the architecture of Scandinavian classicism on the example of historical objects of botanical gardening allows getting a more complete picture of the spheres of influence in the architecture of the Baltic countries.
\end{abstract}

Keywords Classical Architectural Trends, Neoclassicism, Architecture, Botanical Gardening, Scandinavian Architecture, Greenhouses, Typology, Architectural Characteristics

\section{Introduction}

Classical trends pass through the whole history of architecture, starting with ancient Egyptian complexes and ending with the architecture of the 21st century. Classical architectural stylistics is, first of all, rhythmic architecture, with an ordered system. One of the tasks of classical and neoclassical architecture is to create a composition that combines the use of the right volumes with the organization of a significant urban space, including botanical gardens.

Monographic studies of the claimed topic in Russia have not been conducted. The analyzed material represents foreign sources, books, articles, and monographs. In the multivolume encyclopedia "The General History of Arts", it is only discussed in the sixth volume (S. O. Khan-Magomedov devotes several lines to it). Even less attention is paid in the two-volume "General History of Architecture" [1]. The following foreign authors consider Scandinavian classicism as a regional phenomenon in their works: E. Storm [2], B. A. Solbakken [3], N. G. Brekke [4], G. A. Lindvall [5], S. Paavilainen and J. Pallasmaa [6], T. Paulsson [7], S. Ringbom [8], A. Salokova [9], A. D. Smith [10], B. Hyams [11], and U. Gronvold [12]. Also, the history and theory of the design structure of gardens on a global scale are considered in T. Turner's book "European Gardens: History, Philosophy, and Design" [13].

The general history of the architecture of Scandinavia and Finland is analyzed in the works of V. Ya. Kurbatov [14] and A. V. Ikonnikov [15].

The purpose of the study is to identify the nature and degree of influence of classical trends on the architecture and structure of the most significant interior objects of botanical gardening (IOBG) in the largest cities of Sweden and Norway.

The objectives of the study are to compile a typology of the locations of the classic buildings of interior botanical gardening in the studied cities of Sweden and Norway and conduct an enlarged comparison of classical trends in the architecture of buildings of botanical gardens, as well as an analytical generalization of the architectural and urban characteristics of neoclassical buildings in the cities under study. 


\section{Methods}

The general analysis of the IOBG in the classic style allows not only considering the many options and relationships that arose during the development of classical and neoclassical architecture in Sweden and Norway but also compiling a systematic set of buildings of botanical gardening. The following research methods are used in the study:

- a problem-logical method of interconnected study of archival, literary, and cartographic materials, as well as materials of field surveys;

- a formal-stylistic method that allows tracing in detail the genesis of various formal concepts.

The integrated use of these methods allows creating a stereoscopic view of the research method.

In this study, the development and creative principles of masters of architecture are mainly traced on the examples of staged buildings, while much less attention is paid to the architecture of provincial countries, such as Norway in the 19th century.

\section{Results}

Landscape architecture and garden design are separate forms of art with a common and ancient heritage. Landscape architecture, in general, and botanical gardening, in particular, relate to public goods and public spaces. Historically, each society requires a certain policy of creating landscape architecture for each category of land use - to preserve the historical heritage and to create new public places. [16].

Botanical gardening, which is actively developing in European countries, such as Italy, France, Germany, and England [1], has influenced countries with more severe climatic conditions, such as Denmark, Norway, Sweden, Finland, and Russia [9, 15, 17]. The first botanical gardens in Sweden were created in the second half of the 17th century [18]. The first one appeared in the city of Uppsala (1657-1787), located $70 \mathrm{~km}$ north of Stockholm, then in the city of Lund (1690) in the south of the country. In addition, in the center of Stockholm, a botanical garden was formed on a private territory in 1791 and it occupied the current position in the north of the city only in 1885 [4, 19]. In Norway, a botanical garden appeared only at the end of the 19th century and occupied the territory of the Tøyen estate, which once belonged to the abbey in the east of Oslo [12, 20]. The development of botanical gardening just like in other European countries enhanced the status of the country and IOBG became an integral part of the compositions of palace complexes [21]. One such example is the Ulriksdal complex, located in Stockholm north of its center and overlooking the lake, now it is the territory of the Royal National City Park [5].

Using the example of Sweden and Norway, presented in Table 1, we consider the formation of the IOBG architecture and their location in the complex. The architecture of the historical IOBG of the northern countries is distinguished by a combination of functionality, simplicity of form, and integrity of the composition [14]. It traces the external architectural influences of countries such as the Netherlands, Germany, and England [22] and, at the same time, these objects consider the specifics of local climatic conditions, which are reflected in their shape and position on the site [11]. These are quite compact buildings, having in plan predominantly rectangular, П-shaped, Ш-shaped forms. We can distinguish several characteristic positions of IOBG on the site, including: in the center of the site; in the depths of the site; on the edge of the site. 
Table 1. Interior objects of botanical gardening (IOBG)

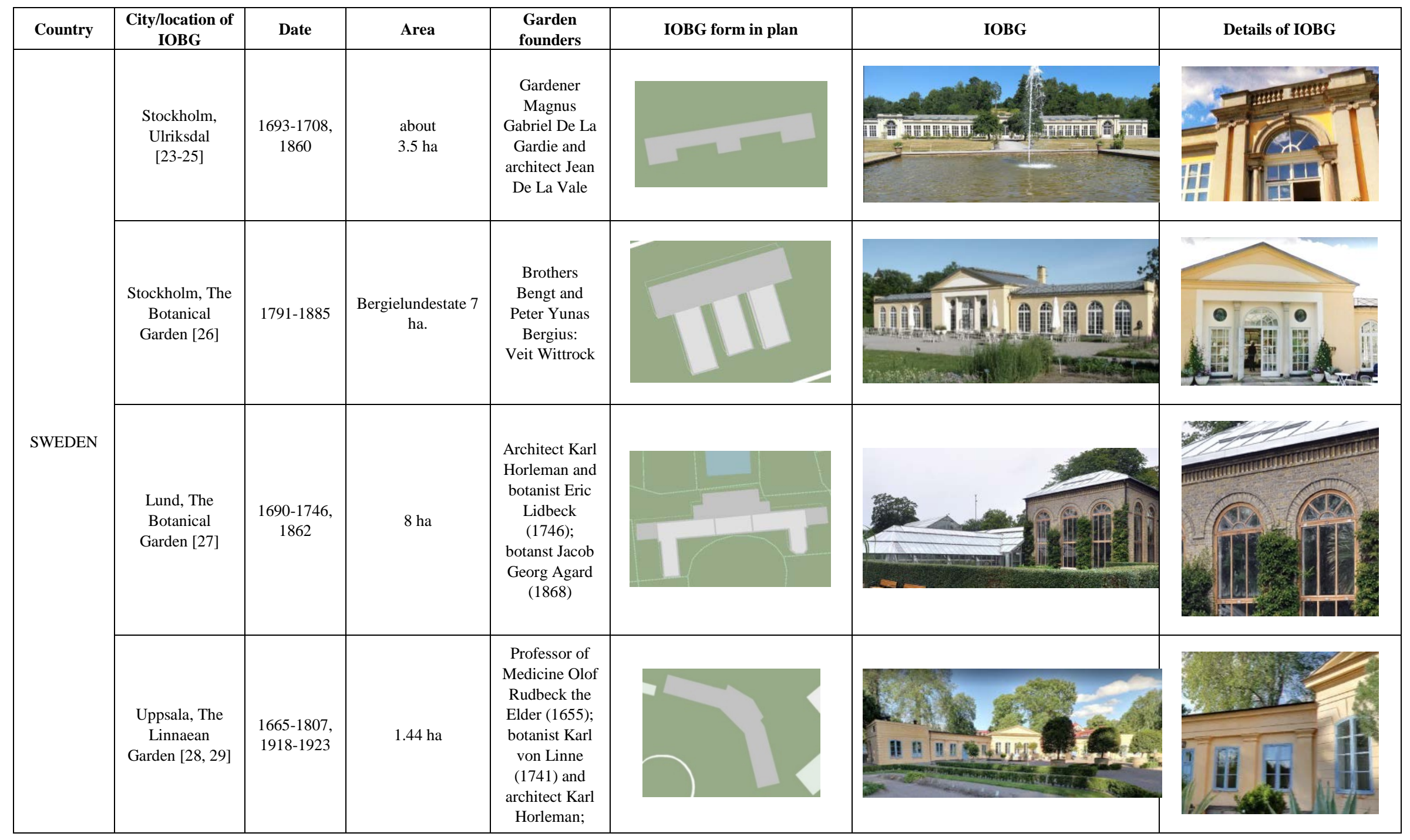


Table 1 continuous

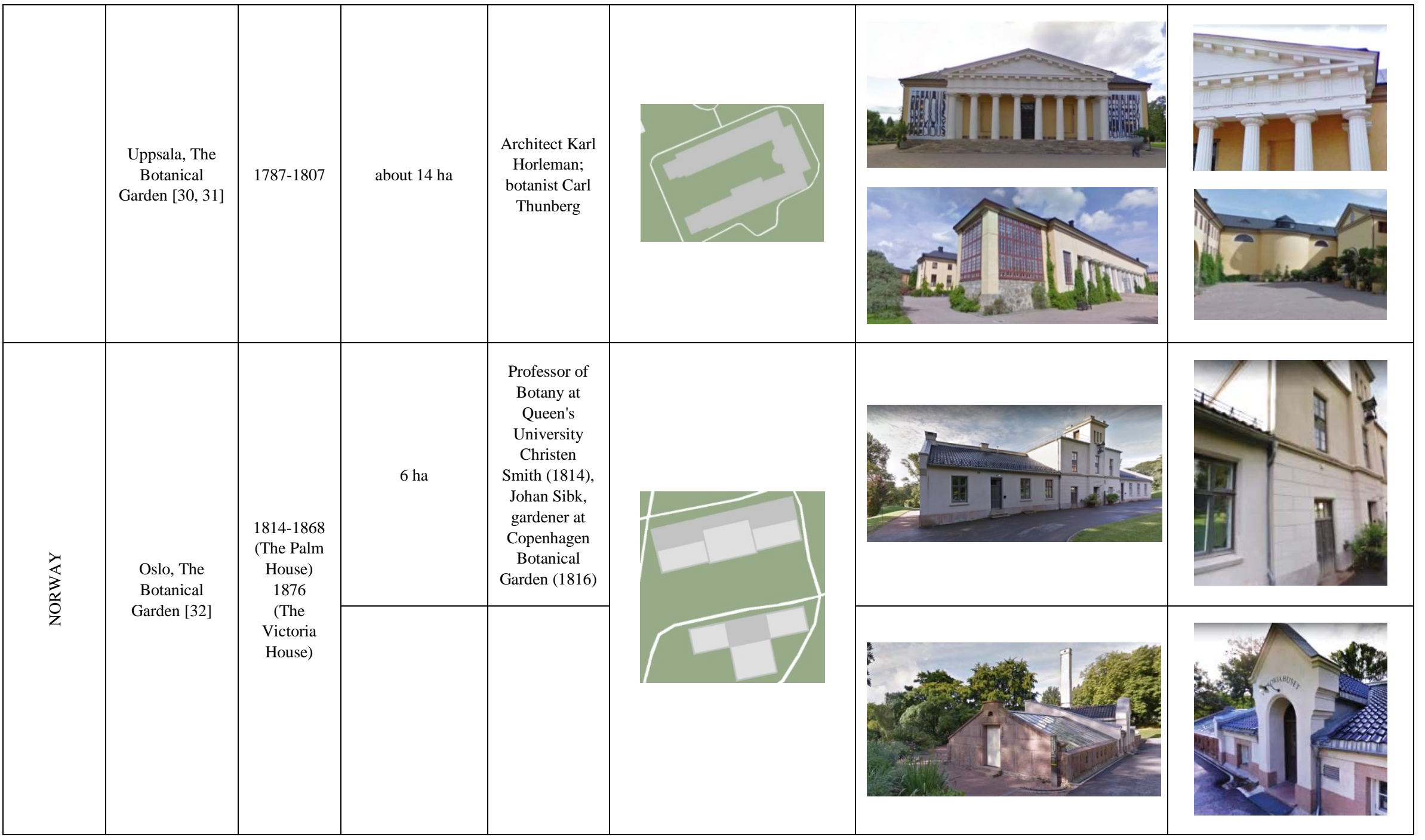


It should also be noted that the objects under consideration have both a dominant and subordinate position, depending on the given compositional relationships. Therefore, for example, in Lund, the greenhouse occupies a dominant central position on the site while other garden objects are located along the perimeter and have a subordinate position. The greenhouses in Uppsala and Stockholm have a close compositional relationship with the castles located nearby while not losing their architectural significance. Despite the identified relationships, objects are fundamentally different from each other in terms of volume and effect on the viewer.

In Uppsala, there is a powerful ח-shaped building with a large central portico of the Doric order, a high porch, and large rectangular windows on the end section of the side wing. The object occupies an advantageous position on the central axis of a rectangular section connected with the palace park. In Ulriksdal, there is an object that is clear and concise in its compositional solution, of much smaller height and elegant detailing, forms, along with the castle with its extended facade, a vast park area, closing one of the main axes. This complex is similar to the complex of Schwetzingen Palace in Germany, which indicates the influence of German architecture (Figure 1) [7, 33].

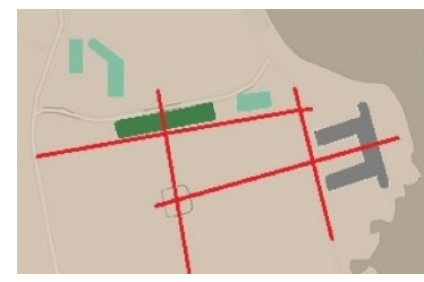

a.

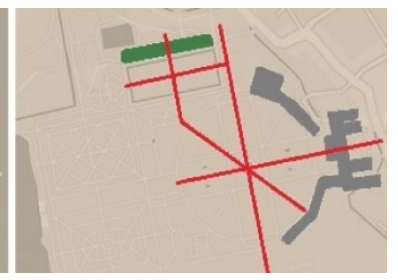

b.
Figure 1. a) Ulriksdal Palace complex, Stockholm, Sweden, b) Schwetzingen Palace complex, Germany

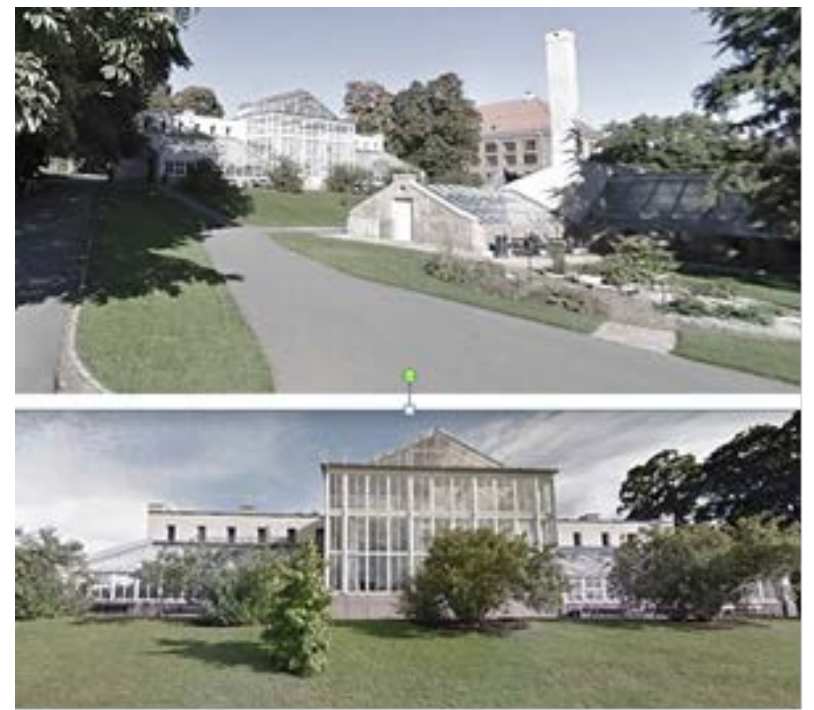

Figure 2. Greenhouse complex of the Botanical Garden in Oslo
Especially it is necessary to highlight the greenhouse complex in Oslo since when arranging the objects, the characteristic terrain was taken into account, contributing to the formation of its special compositional perception. Here, the axial subordination of objects is read only from the lower level from the central entrance to the water conservatory (Figure 2), which is associated with the layout of this site in the English landscape style, which is especially popular in Norway [34].

The considered IOBG can be divided into two main planning types: objects, in terms of which horizontal development dominates; objects that are compact and massive.

As can be seen from Table 1, horizontally elongated volumes of buildings of IOBG have a pronounced central volume along the main facade, due to height and plastic, which emphasizes its symmetry. The central part of the building protrudes forward and is formed by a pediment, portico, or has a longline structure, thus fixing the main entrance. In some cases, the building is solved according to the traditional palace scheme in classicism; the ends of the main facade are decorated with side wings or risalits. At the same time, the specificity of the object is preserved, which is expressed in a combination of stone, metal, and glass materials, as well as in the planning decision, since all the greenhouse branches are located on the same axis, creating a suite of rooms with deep perspectives in the interior. The solution of large stained glass window openings uniformly distributed along the plane of the main facade is quite typical. Their outlines have a traditional rectangular or arched shape, with small or medium glazing. English influence can be seen in the picture of window frames, due to which the IOBG resemble the secular architecture of suburban mansions [8]. The use of tiles in Norwegian greenhouses, as, however, in other buildings, has Dutch roots, since this country was the supplier of this building material to Norway [6].

Profiled base and cornice, plaster simulating rust, frames of door and window openings, columns, and pilasters - all this demonstrates the use of classical techniques in solving the plane of the facades of IOBG. The completion of the main volume of IOBG with one, two, or a four-pitched roof with cornices is widely spread in the northern countries, as it best meets the requirements of classicism [10].

\section{Discussion}

The various principles of the formation and continuity of classical styles have led to the diversity of classical forms in the IOBG in Sweden and Norway. Table 2 shows the differences and similarities of modern and classical features of the architecture of the objects of botanical gardening. 
Table 2. The similarities and differences of classical and modern features of the architecture of objects of botanical gardening

\begin{tabular}{|l|l|}
\hline \multicolumn{1}{|c|}{ Similarities } & \multicolumn{1}{c|}{ Differences } \\
\hline $\begin{array}{l}\text { symmetry as the basis of a } \\
\text { compositional solution [14] }\end{array}$ & $\begin{array}{l}\text { increase in the area of internal } \\
\text { space [1] }\end{array}$ \\
\hline $\begin{array}{l}\text { preservation of enfilade or } \\
\text { reverse movement in objects of } \\
\text { small and medium size [14] }\end{array}$ & $\begin{array}{l}\text { free layout in large objects } \\
{[13]}\end{array}$ \\
\hline $\begin{array}{l}\text { architectural solutions take into } \\
\text { account the latest achievements } \\
\text { in the construction industry [1] }\end{array}$ & $\begin{array}{l}\text { active use of metal structures } \\
{[1,18]}\end{array}$ \\
\hline $\begin{array}{l}\text { remain objects that determine the } \\
\text { territory status [13] }\end{array}$ & \\
\hline
\end{tabular}

The theoretical and practical significance of the study is associated with the fact that the revealed patterns of the relationship between the architectural and urban planning characteristics of interior buildings of classical botanical gardening will replenish the relevant sections of the theory of architecture and can be used in the study of architecture and urban planning in Scandinavian cities.

During the studied period, in Sweden and Norway, a large number of architectural and town-planning complexes and individual structures with signs of synthesizing classicism were created that deserve a separate study.

\section{Conclusions}

As a result of the study, a general enlarged picture of the development of classical styles for historical objects of botanical gardening in Sweden and Norway is compiled and new information is put into scientific circulation, filling the gaps in knowledge of the historical processes in Scandinavian architecture.

Thus, based on the results obtained, it can be concluded that the main techniques in the spatial solution of IOBG are: symmetry, hierarchical axial structure, emphasis on the main facades, active silhouette and proportions gravitating to the golden ratio. Formally, the composition of buildings is distinguished by a variety of both the space-planning structure (frontal, volumetric, angular) and the configuration in the plan. Formal compositions reflect the importance of an object in the structure of greenhouse and botanical complexes. Facade plastic is most clearly shown in structural or ornamental detailing. Swedish classicism of the 18-19th centuries, based on a fundamental nondogmatic understanding of the classical heritage and the characteristic simplicity and purity of forms, symbolizes the rationalist line of neoclassicism, while the architecture of Norway of the 19th century is more romantic.

Throughout the 18-19th centuries, Swedish and Norwegian architects constantly turned to historical classical parallels, but by the mid-19th century, these borrowings had become free [35]. Facade solutions appear synthesizing a neoclassical structure with historicizing decorative-plastic compositions of facades. Since the end of the 19th century, the architecture of IOBG has acquired the features of a specific branch of Scandinavian architecture, which has developed, inter alia, in the course of cultural interaction with European countries that are members of the Baltic region. The architecture of the synthesizing classical styles of Sweden and Norway gave a powerful impetus to the formation of the images of the largest cities in the 19th century, giving a way to the development of professional consciousness of the Scandinavian architectural school.

\section{REFERENCES}

[1] S. O. Khan-Magomedov (ed.). Vseobshchaya istoriya arkhitektury [General History of Architecture], Vol. 10, Izdatelstvo literatury po stroitelstvu, Leningrad, Moscow, 1972.

[2] E. Storm. Regionalism in History, 1890-1945: The Cultural Approach, European History Quarterly, Vol. 33, No. 2, 251-267, 2003.

[3] B. A. Solbakken. Fra nyklassisisme til funksjonalisme i den sosiale boligbyggingen - en analyse av Ilaløkken og Sinsenbyen, Hovedoppgave i kunsthistorie, Universitetet i Oslo, 2001.

[4] N. G. Brekke, P. J. Nordhagen, S. S. Lexau. Norsk arkitekturhistorie: frå steinalder og bronsealder til det 21. Hundreåret, Samlaget, Osclo, 2003.

[5] J. Lindvall, M. Plunger. The Swedish art of building, Almqvist \& Wiksell International, Stockholm, 1992.

[6] S. Paavilainen and J. Pallasmaa (eds.). Nordic Classicism 1910-1930, Museum of Finnish Architecture, Helsinki, 1982.

[7] T. Paulsson. Scandinavian architecture. Building and society in Denmark, Finland, Norway and Sweden from the iron age until today, Leonard Hill, London, 1958.

[8] S. Ringbom. Stone, style and truth. The vogue for natural stone in Nordic architecture 1880-1910, Vammala, 1987.

[9] A. Salokova. Modern Architecture in Finland, New-York, 1966.

[10] A. D. Smith. Nationalism and Modernism. A Critical Survey of Recent Theories of Nations and Nationalism, Routledge, London, 1998.

[11] I. B. Hyams, Danish Vernacular - Nationalism and History Shaping Education, Roskilde University, Roskilde, 2005.

[12] U. Gronvold. A history of buildings: 1000 years of Norwegian architecture, Norsk Arkitekturmuseum, 1997.

[13] T. Turner. European Gardens: History, Philosophy and Design, Routledge, 2011.

[14] V. Ya. Kurbatov. Podgotovka i razvitiye neoklassicheskogo stilya [Preparation and development of the neoclassical style], Staryye gody, July-September, 1911. 
[15] A. V. Ikonnikov. Novaya arkhitektura Finlyandii [New architecture of Finland], Stroyizdat, Moscow, 1971.

[16] Gardenvisit.ru. Landscape architecture, Online available from https://www.gardenvisit.com/landscape_architecture

[17] M. C. Donnelly. Architecture in the Scandinavian countries, MIT Press, Cambridge, Mass., 1992.

[18] A. K. Sytin. Zodchii chertogov flory (k 300-letiu so dnia rozhdeniia Karla Linneiia) [The Architect of the Chamber of Flora (on the 300th Anniversary of the Birth of Karl Linnaeus)], Samarskaia Luka, Vol. 16, No. 3(21), 363-371, 2007.

[19] H. Abrahamsen. Building in Norway, Oslo: The Royal Norwegian Ministry of Foreign Affairs, 46-47, 1959.

[20] A. Gunnarsjaa. Norges arkitekturhistorie, Abstrakt, Oslo, 2006.

[21] D. J. H. Stöver, The Life of Sir Charles Linnæus: To which is Added, a Copious List of His Works, and a Biographical Sketch of the Life of His Son, B. and J. White, 1794.

[22] M. Mann. Orangeribyggnaden och Botaniska trädgården, 2000.

[23] Gardenvisit.com. Jakobsdal Garden - Ulriksdal Slottstardsgard, Online available from https://www.gardenv isit.com/gardens/jakobsdal

[24] De Kungliga Slotten. Ulriksdal Palace Park, Online available from https://www.kungligaslotten.se/english/royal -palaces-and-sites/ulriksdal-palace/ulriksdal-palace-park.ht $\mathrm{ml}$

[25] Gardener.ru. Ulriksdal Palace Park, Online available from https://www.gardener.ru/gap/garden_guide/page358.php?ca $\mathrm{t}=277$
[26] Bergianska trädgården. Online available from http://www.bergianska.se/

[27] Gardener.ru. Lund University Botanical Garden, Online available fromhttps://www.gardener.ru/gap/garden_guide/p age4032.php?cat=277

[28] Gardenvisit.com. Linnetradgarden (Linnaeus Garden), Online available fromhttps://www.gardenvisit.com/gardens /linnetradgarden-linnaeus_garden

[29] Uppsala Universitet. Uppsala University Botanical Garden, Online available from https://web.archive.org/web/2011060 8075542/http://www.botan.uu.se/Historia/History.html

[30] Gardenvisit.com. Uppsala Botanic Garden, Online available from https://www.gardenvisit.com/gardens/uppsala_botanic_gard

[31] Slottsguiden.info. Uppsala slott, Online available from https://www.slottsguiden.info/slottdetalj.asp?id=26

[32] University of Oslo. Natural History Museum, Botanical Garden, Online available from https://www.nhm.uio.no/eng lish/visiting/botanical-garden/

[33] C. Sitte. Der Städtebau nach seinen künstlerischen Grundsätzen, Carl Graeser, Vienna, 1889, Translated by G.R. Collins and C. Crasemann Collins, City Planning According to Artistic Principles, Phaidon Press, London, 1965, rev. ed. Rizzoli, New York, 1986.

[34] B. J. Hovde. The Scandinavian Countries, 1720-1865. The Rise of the Middle Classes, Kennikat Press, New York and London, 1972.

[35] J. S. Curl. A Dictionary of Architecture and Landscape Architecture, Oxford University Press, Oxford, 2006. 